\section{Organics profit from premiums}

Organic crop production costs more than traditional farming, but it can be economically viable as long as the organic crops are sold at premium prices, according to a study of alternative farming practices.

This is the last season of the 12-year Sustainable Agriculture Farming Systems (SAFS)

Project. The UC Davis study is comparing conventional cultural practices with low-input and organic farming systems for crop rotations typical to the Sacramento Valley.

The 28-acre research project includes a 2-year conventional system alternating tomatoes and wheat and a 4-year, five-crop rotation for conventional, low-input and organic systems. The 4-year rotations include processing tomatoes, safflower, corn and a winter grain (wheat for the conventional systems and an oat/vetch mix for the low-input and organic systems) followed by a double crop of beans. The low-input and organic systems incorporate alternatives to conventional pest-control practices and the use of nitrogen-fixing cover crops preceding the planting of tomatoes, safflower and corn. Furrow irrigation is used for crop production in all four systems.

Some consumers are willing to pay more for produce grown without pesticides than for conventionally grown produce. As demand for organic food rises, more organically grown produce has been garnering price premiums.

From 1989 through 1999, organic plots that received premiums showed an average net return of $\$ 258$ per acre per year, whereas conventional 2-year plots showed a net return of $\$ 262$ per acre, says UC Davis agricultural economist Karen Klonsky, who evaluated the whole farm performance of each farming practice. Without price premiums, the organic system lost an average of $\$ 56$ per acre.

With price premiums, the organic system showed the highest net income of all the 4-year systems in 8 out of 10 years and exceeded the 2year conventional system in 4 years. On average, the low-input system outperformed the organic system with conventional prices, but fell below the two conventional systems.

To compare the magnitudes of the price premiums received for the organic SAFS crops, the premiums can be expressed as the percentage over conventional prices. Using this measure from 1989 to 1999 , organic processing tomatoes have averaged a $54 \%$ price premium, organic beans $41 \%$, organic corn $29 \%$ and organic safflower $28 \%$.

"Looking at the most recent five years," Klonsky says, "the relative price premiums have changed, with tomatoes falling to only $38 \%$, and beans, corn and safflower rising to $64 \%, 44 \%$ and $40 \%$, respectively. Processing tomatoes are the only crop for which the price premium actually decreased steadily from 1989 to 1996 , but increased in 1997 and again in 1998."

Organic price premiums for beans were not available until 1992 , increasing steadily to $94 \%$ in 1996, dropping dramatically to $17 \%$ in 1997 and recovering to $50 \%$ in 1998 . Corn premiums

have been the most volatile, ranging from $7 \%$ to $125 \%$ over the conventional price, largely due to the influence of production in other states. Organic safflower premiums have risen consistently, reaching $56 \%$ in 1998.

SAFS project leader and UC Davis agronomist Steve Temple noted the SAFS Project has generated a wealth of invaluable information that farmers are putting to use.

"Some of the most important results from SAFS have shown us where we can reduce synthetic fertilizer inputs, how to manage cover crops and crop residue, and how we can man-

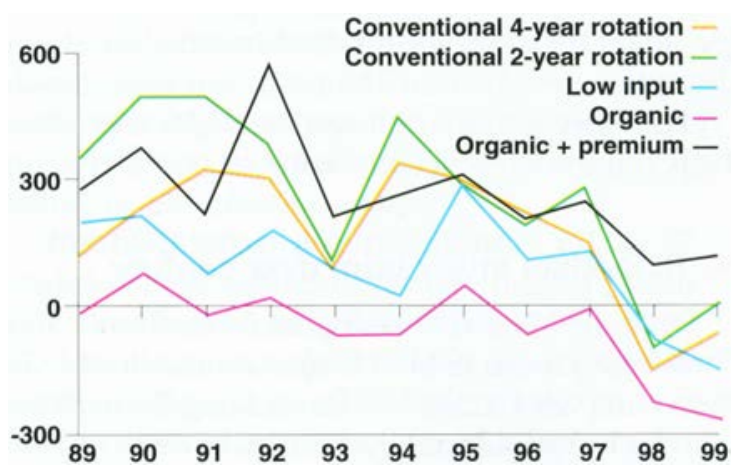

Fig. 1. Whole farm net returns for SAFS project.

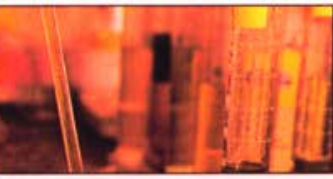




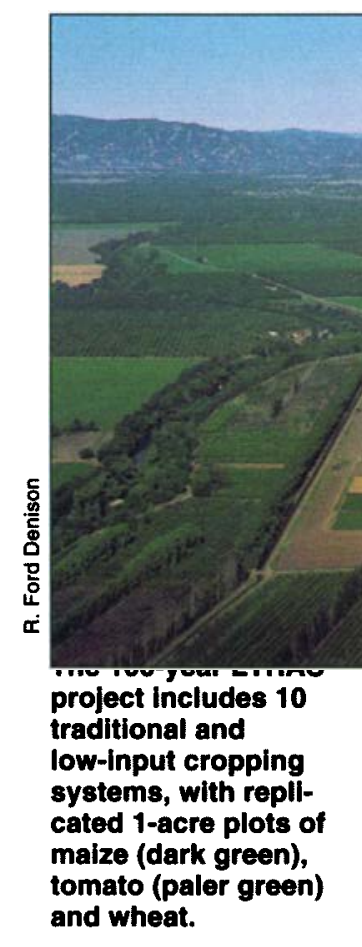

age weeds and pests with fewer pesticides,"

Temple says. "We also developed a clearer understanding of the economic opportunities and limitations to organic farming practices."

For example, weed control can be a challenge without herbicides.

"We've tried mulches, flaming, acetic acid, even geese in wet years when El Niño made it too difficult to get into fields," says Tom Lanini, UC Davis weed specialist. Buried drip irrigation is expensive $-\$ 600$ to $\$ 700$ per acre - but the extra expense to avoid wetting the soil surface where weeds grow could be justified in highvalue crops like tomatoes.

The SAFS Project is a collaborative effort involving UC Cooperative Extension farm advisors and specialists, campus-based scientists and growers.

The primary objective is to compare systems performance with respect to (1) abundance and diversity of weed, pathogen, arthropod and nematode populations; (2) differences in soil biology, physical and chemical properties and water relations; (3) crop growth, yield and quality; and (4) economic viability.

"After this season, we plan to retool and modify the project into a farming systems experiment focused on conservation tillage," says Temple.

For more information, see the SAFS Web site: http://agronomy.ucdavis.edu/safs/

\section{- Scientists study farm over century}

Even the 12-year Sustainable Agriculture Farming Systems (SAFS) Project seems short term compared to the UC Davis Long Term Research on Agricultural Systems (LTRAS) project. A 100 -year experiment occupies about one-third of the 300-acre LTRAS site.
While the primary objective of SAFS has been to test cropping systems that require less fertilizer and pesticides, LTRAS scientists focus on water, weeds, and threats to sustainability that may only be detectable over decades.

"Short-term trends can be poor predictors of sustainability," explains R. Ford Denison, director of LTRAS. At the Rothamsted Experiment Station, in England, yields in one system increased for 40 years, then decreased to near zero over the next few decades. Many soil properties that determine crop yield and control nitrate leaching change over decades rather than years. Organic matter doubled in another system at Rothamsted, but it took almost 100 years. At LTRAS, 2000 was the first year that water used by cover crops had an adverse effect on following crops; nitrogen-fixing weeds outcompeted other weed species in unfertilized control plots; and disease caused significant losses in some wheat systems. "We don't know yet whether these results represent the beginning of longterm trends," Denison says.

Researchers at LTRAS are attempting to learn the relationship between sustainability and external inputs. The 10 cropping systems differ mainly in how much irrigation water (which may become increasingly scarce in California) or nitrogen fertilizer is used (if any).

The scientists characterized soil conditions before the experiment began and collected "time-zero" archival samples from the 1-acre plots before planting wheat and cover crops in fall 1993.

One system follows organic guidelines and several include nitrogen-fixing legume cover crops. Sustainability will be determined from long-term trends in yield, profitability, efficiency in use of limited resources (such as water or energy), and environmental impact, such as leaching of nitrate or pesticides. Scientists are monitoring trends in key soil properties, such as organic matter, weed seeds, $\mathrm{pH}$ and salinity to see whether any of these are good predictors for long-term sustainability.

While acting as an "early warning system" to detect gradual but potentially harmful longterm trends, the project can make important short-term contributions to agriculture. "Inexpensive methods developed at LTRAS to obtain the data needed for precision farming have already been applied in on-farm research," Denison says.

For more information, see the LTRAS Web site: http://LTRAS.ucdavis.edu 